\title{
Proof on the Divergence Times of Two Sympatric Species, Rhynchophorus ferrugineus and $R$. vulneratus (Coleoptera: Curculionidae) by Molecular Clock Analysis
}

\author{
Ameyra AMAN-ZUKI ${ }^{1}$ \\ Izfa Riza HAZMI ${ }^{4}$
}

\author{
Siti Zafirah GHAZALI ${ }^{2}$ \\ Aqilah Sakinah BADRULISHAM ${ }^{3}$ \\ Othman NURUL WAHIDA ${ }^{5}$ \\ Salmah YAAKOP ${ }^{* *}$
}

Centre for Insect Systematics, Department of Biological Sciences and Biotechnology, Faculty of Science and Technology, Universiti Kebangsaan Malaysia, 43600 Bangi, Selangor, MALAYSIA

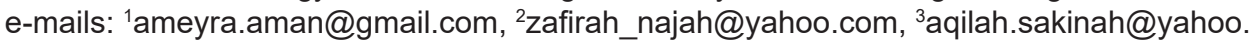

com, ${ }^{4 i z f a h a z m i @ u k m . e d u . m y, ~}{ }^{5}$ wahida@ukm.edu.my, ${ }^{6 *}$ salmah78@ukm.edu.my

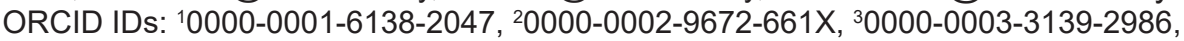
${ }^{4} 0000-0003-0933-7083,{ }^{5} 0000-0001-5998-6677,{ }^{6 *} 0000-0002-2998-8716$

\begin{abstract}
Molecular clock analysis on the oil palm weevil has separated the Red Palm Weevil, Rhynchophorus ferrugineus and Asiatic palm weevil, Rhynchophorus vulneratus as two sympatric species. Calibration was performed using the fossil of $R$. cruentatus which had evolved approximately 1 mya using sequences data of combined $\mathrm{COI}$ and $\mathrm{Cytb}$. Divergence time indicated that $R$. cruentatus, the outgroup species evolved around $80.598 \pm 10$ mya and finally speciated to form $R$. ferrugineus $(\approx 1.926 \pm 10$ mya) and $R$. vulneratus $(\approx 4.857 \pm 10$ mya). Additionally, the construction of Neighbour Joining $(\mathrm{NJ})$ and Maximum Parsimony (MP) trees showed distinct separation using $\mathrm{COI}$, Cytb and combination of $\mathrm{COI}$ and $\mathrm{Cytb}$. These findings were highly supported by genetic distance analysis. Although a limited number of individuals from the small geographical area was used in this study, the genetic molecular clock analysis of mitochondrial data was able to effectively differentiate both species. These results reveal the first analysis to use the molecular clock to confirm the separation of these two sympatric species.
\end{abstract}

Key words: Red Palm Weevil, fossil, time divergence, molecular clock, evolution, mitochondria, $\mathrm{COI}$ and Cytb.

Aman-Zuki, A., Ghazali, S.Z., Badrulisham, A.S., Hazmi, I.R., Wahida, O.N., \& Yaakop, S. (2021). Proof on the divergence times of two sympatric species, Rhynchophorus ferrugineus and $R$. vulneratus (Coleoptera: Curculionidae) by molecular clock analysis. Journal of the Entomological Research Society, 23(1), 11-26. 


\section{INTRODUCTION}

Red Palm Weevil (RPW), Rhynchophorus ferrugineus (Olivier, 1970) is categorised under the family Curculionidae of the weevil species and poses a serious threat to the trees of Arecaceae family (Molet, Roda, \& Jackson, 2011). The invasion of the RPW significantly reduces the yield of coconut trees in the west coast of Peninsular Malaysia (Idris et al, 2014), and other palm trees e.g. dates and coconut around the world (Mazza et al, 2014). This species has complicated biology, for instance, the pest inhabits inside the tree trunk (Wattanapongsiri, 1966), and the larval and adult stages feed on different resources that renders developing control strategies difficult.

The adult of RPW displays a high degree of color polymorphism, especially for the two species namely $R$. ferrugineus and $R$. vulneratus. This color polymorphism has been discussed and studied by the taxonomists and other researchers. Hallet et al (1993) have studied the aggregation pheromones $R$. ferrugineus and $R$. vulneratus and stated that there was no significant difference between the two species in pheromone production, according to the chemical composition. According to Hallet, Crespi, \& Borden (2004), the two colour-morphs in the weevil species, which is having orange or black marking, and black or red stripe are recognized as a single species, $R$. ferrugineus. Hallet et al (2004) have synonymise both species based on the morphological characters, molecular-genetic and breeding data. All that findings have claimed synonymous in both species, consequently invited a great debate among the researchers to prove that both species are cryptic species due to sympatric speciation.

The $R$. ferrugineus and probably its synonymized species, $R$. vulneratus are native from South-East Asia. They have expanded their distributional ranges, which indicates a geographic overlap in both species ( $R$. ferrugineus and $R$. vulneratus) (Giblin-Davis, Faleiro, Jacas, Peña, \& Vidyasagar, 2013). Rugman-Jones et al (2013) noted that distribution in the $R$. ferrugineus was distributed worldwide and had been found native to the continental southeast Asia (northern and western parts), Sri Lanka and Philippines, while $R$. vulneratus was distributed more to the southern part across Indonesia and had invaded California, U.S.A. It was also suggested that a few cryptic species of the Rhyncophorus might exist within the studied populations of both species. Thus, it is permissible to state that both species gathered in this study were species are native to Malaysia and other countries in the native range.

Both species have spread to other countries and regions through the import and export of dates and coconut plants within and outside the country (El-Mergawy et al, 2011). The study by Rugman-Jones et al (2013) has proven that $R$. ferrugineus and $R$. vulneratus are two different species using molecular-genetic of the $\mathrm{COI}$ mitochondrial data. The phylogenetic tree from the study has also been generated in three distinct lineages of Rhynchophorus, which are $R$. ferrugineus, $R$. vulneratus and $R$. bilineatus. The need for thorough research on these two sympatric species was raised and highlighted due to their high degree of polymorphism in coloration (Hallett et al 2004). Due to all the above reasons, both species were claimed as sympatric species, whereby either $R$. vulneratus or $R$. ferrugineus had evolved earlier, but both had finally been found inhabiting the same locality. 
Proof on the Divergence Times of $R$. ferrugineus and R. vulneratus

Therefore, this study aimed to investigate the difference between the Red Palm Weevil, Rhynchophorus ferrugineus (Olivier) and Asiatic Palm Weevil, R. vulneratus (Panzer) (Coleoptera: Curculionidae) using molecular data ( $\mathrm{CO}$ and $\mathrm{Cytb}$ ) by implementing molecular clock analysis to estimate the divergence time of each species. With that, the species separation can be seen clearly.

\section{MATERIAL AND METHODS}

\section{Insect sampling and morphological identification}

The sampling of palm weevils was conducted between April to June 2013. A total of eight palm weevils were collected from Kuala Selangor, Selangor ( $R$. vulneratus) and Kuala Terengganu, Terengganu ( $R$. ferrugineus), located at the center and east-coast part of Peninsular Malaysia (Fig. 1). The specimens collected were preserved in $70 \%$ alcohol and brought to the Entomology Laboratory in Universiti Kebangsaan Malaysia (UKM) for morphological identification prior to the molecular work. The morphological identification was based on taxonomical keys by Wattanapongsiri (1966) using the StemiD4 stereo microscope.

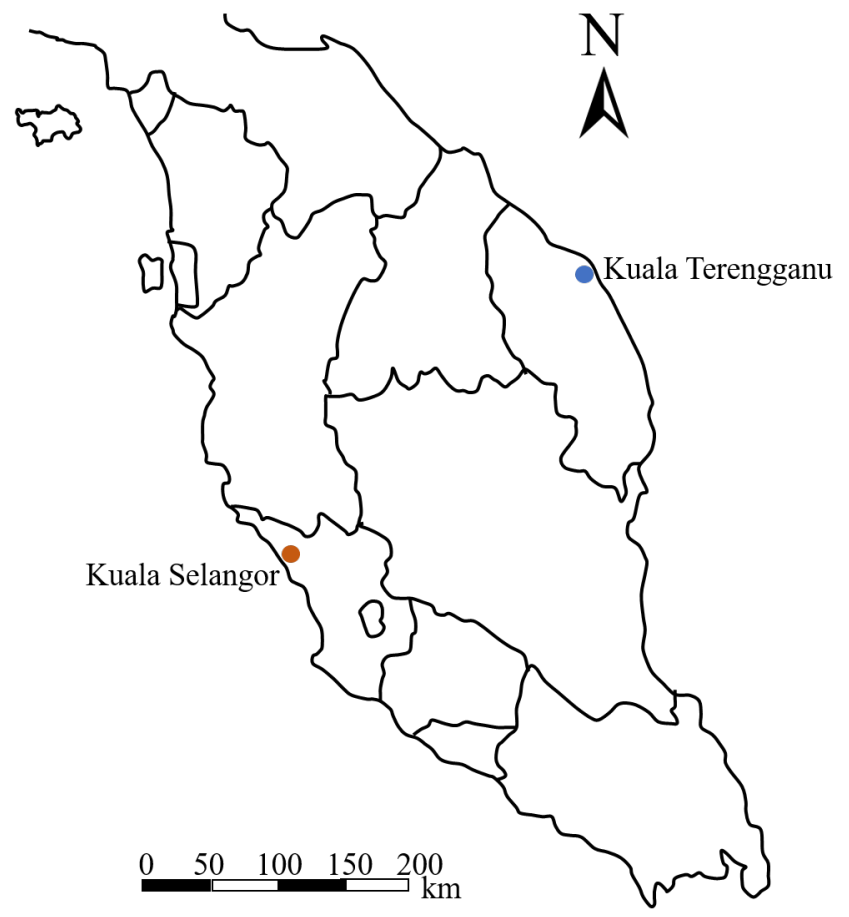

Fig. 1. Map of samples location collected in this study. 


\section{DNA extraction and PCR amplification}

Tissue samples were taken from the posterior part of the metasomal tergite of the black or red stripe weevil (R. vulneratus), and the orange or black marking weevil ( $R$. ferrugineus) (Rugman-Jones et al, 2013). DNA extraction of the tissue samples was performed using DNeasy Blood \& Tissue Kit (Qiagen, Valencia, California, USA).

The extracted samples were then subjected to PCR amplification. Optimization of PCR amplification for cytochrome oxidase subunit I (COI) and cytochrome B (Cytb) region were done for each of the individuals. A total of $25 \mu \mathrm{lPCR}$ mixture consisted of $0.5 \mu \mathrm{l}$ of $0.2 \mathrm{mM}$ dNTPs, $10 \mathrm{pmol}$ of each primer, $1.25 \mathrm{U}$ of Taq polymerase, and $1 \mu \mathrm{l}$ of $15 \mathrm{mM} \mathrm{MgCl}_{2}$ from Vivantis were prepared. PCR was performed using MyGene MG96G Thermalcycler or Thermocycler Perkin Elmer 240 under different conditions for each primer combination, starting with initial denaturation for 3 minutes at $94^{\circ} \mathrm{C}$, followed by 39 cycles; denaturation for $1 \mathrm{~min}$ at $92^{\circ} \mathrm{C}$, annealing for 1 min at $47^{\circ} \mathrm{C}$, an extension for $1 \mathrm{~min}$ at $72^{\circ} \mathrm{C}$ and final extension for 5 mins at $72^{\circ} \mathrm{C}$ (Mohammed, Aman-Zuki, Yusof, S., Md-Zain, \& Yaakop 2017; Halim et al, 2018; Aman-Zuki, Mohammed, Md Zain, \& Yaakop 2019). Two sets of universal primers used were COI [Ron (5' GGA TCA CCT CAT ATA GCA TTC CC 3') (Forward); Nancy (5' CCC GGT AAA AAT TAA AAT ATA AAC TTC 3') (Reverse)] (Simon et al, 1994; Monteiro \& Pierce, 2001) and Cytb [(CB-J-10933 5' TCT TTT TGA GGA GCW ACW GTW ATT AC 3'; CB-N-11367 5' AAT TGA ACG TAA AAT WGT RTA AGC AA 3'] (Smith, Kambhampati, Völkl, \& Mackauer, 1999; Smith \& Kambhampati, 1999) to yield 600 bp and 560 bp fragments.

\section{Sequencing and phylogenetic analyses}

PCR products for each species were then sent to First Base Sdn. Bhd., Selangor, Malaysia for sequencing. The sequences were then edited using Sequencher 4.8 and aligned using MacClade 4.08. Before the phylogenetic analyses, the genetic distance between the species was obtained for both markers. For phylogenetic analyses (Table 1), the Neighbor Joining (NJ) tree was constructed using Kimura-2 parameter and the bootstrap was analysed (Kimura \& Ohta, 1972). The maximum parsimony (MP) tree(s) were generated using PAUP* 4.0- test version 4.0d63 (Swofford, 1998) to get the most parsimonious tree(s). A heuristic parsimony search (Hillis, Moritz, \& Mable, 1996) was performed using 100 replicates of random addition sequences, including the TBR (tree bisection reconnection) option for branch swapping. Each base was treated as an unordered character with equal weight, with gaps treated as missing data. Statistical support was obtained by bootstrap analysis with 100 replications (Felsenstein, 1985).

For Bayesian analysis $(\mathrm{BI})$, nucleotide substitution model was selected using jModelTest 2.1.4 (Ronquist et al, 2012). Bayesian Inference trees for COI, Cytb and combined $\mathrm{CO}$ and Cytb were generated using MrBayes 3.1.2 software with Markov Chain Monte Carlo algorithm (Huelsenbeck, Larget, \& Alfaro 2004). The length of the generation chain was analyzed until the value of split frequency is lower than 0.01 . The burnin of the final tree was set up at 25\% (Drummond, Ho, Phillips, \& Rambaut 2006). 
Proof on the Divergence Times of $R$. ferrugineus and $R$. vulneratus

Table 1. List of samples used in the molecular and phylogenetic analyses.

\begin{tabular}{|l|l|l|l|l|}
\hline Code sample & Species & Locality & $\begin{array}{l}\text { Accession } \\
\text { No. COI }\end{array}$ & $\begin{array}{l}\text { Accession } \\
\text { No. Cytb }\end{array}$ \\
\hline K01 & Rhynchophorus vulneratus & Malaysia: Selangor, Kuala Selangor & MG051024 & MG051032 \\
\hline K02 & Rhynchophorus vulneratus & Malaysia: Selangor, Kuala Selangor & MG051025 & MG051033 \\
\hline K04 & Rhynchophorus vulneratus & Malaysia: Selangor, Kuala Selangor & MG051026 & MG051034 \\
\hline K05 & Rhynchophorus ferrugineus & Malaysia: Terengganu: Kuala Terengganu & MG051027 & MG051035 \\
\hline K06 & Rhynchophorus ferrugineus & Malaysia: Terengganu: Kuala Terengganu & MG051028 & MG051036 \\
\hline K07 & Rhynchophorus ferrugineus & Malaysia: Terengganu: Kuala Terengganu & MG051029 & MG051037 \\
\hline K08 & Rhynchophorus ferrugineus & Malaysia: Terengganu: Kuala Terengganu & MG051030 & MG051038 \\
\hline K10 & Rhynchophorus ferrugineus & Malaysia: Terengganu: Kuala Terengganu & MG051031 & MG051039 \\
\hline GBMIN32436 & Rhynchophorus ferrugineus & Japan & GU581524 & - \\
\hline GBMIN32437 & Rhynchophorus ferrugineus & Japan & GU581522 & - \\
\hline GBMIN32267 & Rhynchophorus ferrugineus & Japan & GU581521 & - \\
\hline GBMIN32268 & Rhynchophorus ferrugineus & Japan & GU581519 & - \\
\hline GBMIN32269 & Rhynchophorus ferrugineus & Japan & GU581518 & - \\
\hline GBMIN32439 & Rhynchophorus ferrugineus & Japan & GU581517 & - \\
\hline & Rhynchophorus palmarum & - & GU581629 & GU581656 \\
\hline
\end{tabular}

\section{Molecular clock analysis}

The analysis to measure and estimate the time divergence of the RPW species was done using a combination sequence data of $\mathrm{COI}$ and Cytb. Two compatible softwares used for the time divergence analysis were BEAUti and BEAST version v1.10.4 (Suchard et al, 2018). The nucleotide substitution model was chosen using jModelTest (Ronquist et al, 2012) prior to analysis. The chosen model was HKY+G. The clock partitioning was set for ingroup and outgroup taxa with $R$. cruentatus (AY131113) as outgroup and set with tip date from time fossil for Palmetto Weevil, Rhynchophorus cruentatus Fabricius (Insecta: Coleoptera: Curculionidae) which is 1 million years ago (Weissling \& Giblin-Davis, 1997). Lognormal relaxed clock was chosen for clocks model referring to Heath, Huelsenbeck, \& Stadler (2014) to remove the assumption of a strict molecular clock in the uncertain or unresolved topology of phylogenetic tree. The Speciation: Birth-Death Process was chosen for the tree before estimation of the speciation with the rate of birth (branching speciation) and death (extinction) incorporated in the lineage following (Stadler, Gavryushkina, Warnock, Drummond, \& Heath, 2018) and (Herbst, 1795). The time fossil for Rhynchophorus used was 48.6-40.4 \pm 10 mya as reported from (Rambaut $\&$ Drummond, 2015). The length of the chain for this analysis was fixed at 10,000,000 generations of Markov Chain Monte Carlo with tree sampling at every 1000 generations. The burnin of the final tree was set up at 25\% from total tree using TreeAnnotator 1.7.5 (Drummond \& Rambaut, 2007). Molecular clock tree was visualized using FigTree 1.4.2 (Posada, 2008). 


\section{RESULTS}

\section{Morphological identification}

The weevil samples were identified based on the color morph according to Wattanapongsiri (1966) description, in which orange with black marking was characterized for the $R$. ferrugineus, while black with red stripe was for the $R$. vulneratus. Three individuals collected from Kuala Selangor were identified as $R$. vulneratus (K1-K2, K4), while other specimens collected from Kuala Terengganu (K5-K8, K10) were identified as $R$. ferrugineus.

\section{Phylogeny tree reconstruction and genetic distances}

All individuals were successfully extracted and amplified using both markers, viz. $\mathrm{COI}$ and Cytb in the length of 600 and $560 \mathrm{bp}$. Phylogeny analyses have confirmed that both spotted and striped weevils were located in different clades for each molecular data in NJ, MP and BI analyses (Figs. 2a-c, 3a-c and 4a-c). In the phylogeny results, Rhynchophorus vulneratus and $R$. ferrugineus are located in different clades and supported with $100 \%$ bootstrap values in both analyses. The specimens from Japan were added in the $\mathrm{CO} /$ datasets and yet still showed the separation of the outgroup and ingroups ( $R$. cruestatus and $R$. palmarum) at different lineages and highly supported with $100 \%$ bootstrap value. The genetic data differences showed that individuals of the $R$. ferrugineus from Malaysia and Japan were 0.047 (Table 2).

Table 2 and 3 show the genetic distance for individuals in $R$. vulneratus and $R$. ferrugineus using $\mathrm{COI}$ and $\mathrm{Cytb}$ data. Genetic distance for both $\mathrm{COI}$ and $\mathrm{Cytb}$ markers showed that individuals among the $R$. vulneratus had high divergences compared to $R$. ferrugineus. In COI, genetic distances among the $R$. vulneratus were 0.010-0.029, while among $R$. ferrugineus the values were $0.000-0.047$. In Cytb, genetic distances among $R$. vulneratus were $0.016-0.019$, while among $R$. ferrugineus the values were 0.000-0.05.

\section{Estimating divergence time}

The result of molecular clock analysis (Fig. 5) based on the combination of $\mathrm{CO}$ and Cytb (1367 bp) molecular data showed different divergence times in both sympatric species ( $R$. vulneratus and $R$. ferrugineus) and the outgroup species, $R$. cruentatus Fabricius (Coleoptera: Curculionidae). The divergence times showed that $R$. cruentatus had diverged earlier compared to $R$. vulneratus and $R$. ferrugineus since around $80.598 \pm 10$ mya followed by $R$. vulneratus at $\approx 4.857 \pm 10$ mya and the latest was $R$. ferrugineus at $\approx 1.926 \pm 10$ mya.

\section{DISCUSSION}

In this paper, the Malaysian samples were taken as a model species to measure the time divergence of Rhynchophorus ferrugineus and $R$. vulneratus from the Oriental region. Although a small-scale area (Peninsular Malaysia only) was considered in 
Proof on the Divergence Times of $R$. ferrugineus and $R$. vulneratus

this study, it was very significant in influencing the speciation process. In this study, $R$. palmarum was selected as the outgroup for comparing the two cryptic species. According to Löhr, Vásquez-Ordóñez, \& Lopez-Lavalle (2015), the cryptic species ( $R$. ferrugineus and $R$. vulneratus) was distinctly separated from the $R$. palmarum using $\mathrm{COI}$ sequences data with the support of phylogenetic analysis in species clustering.

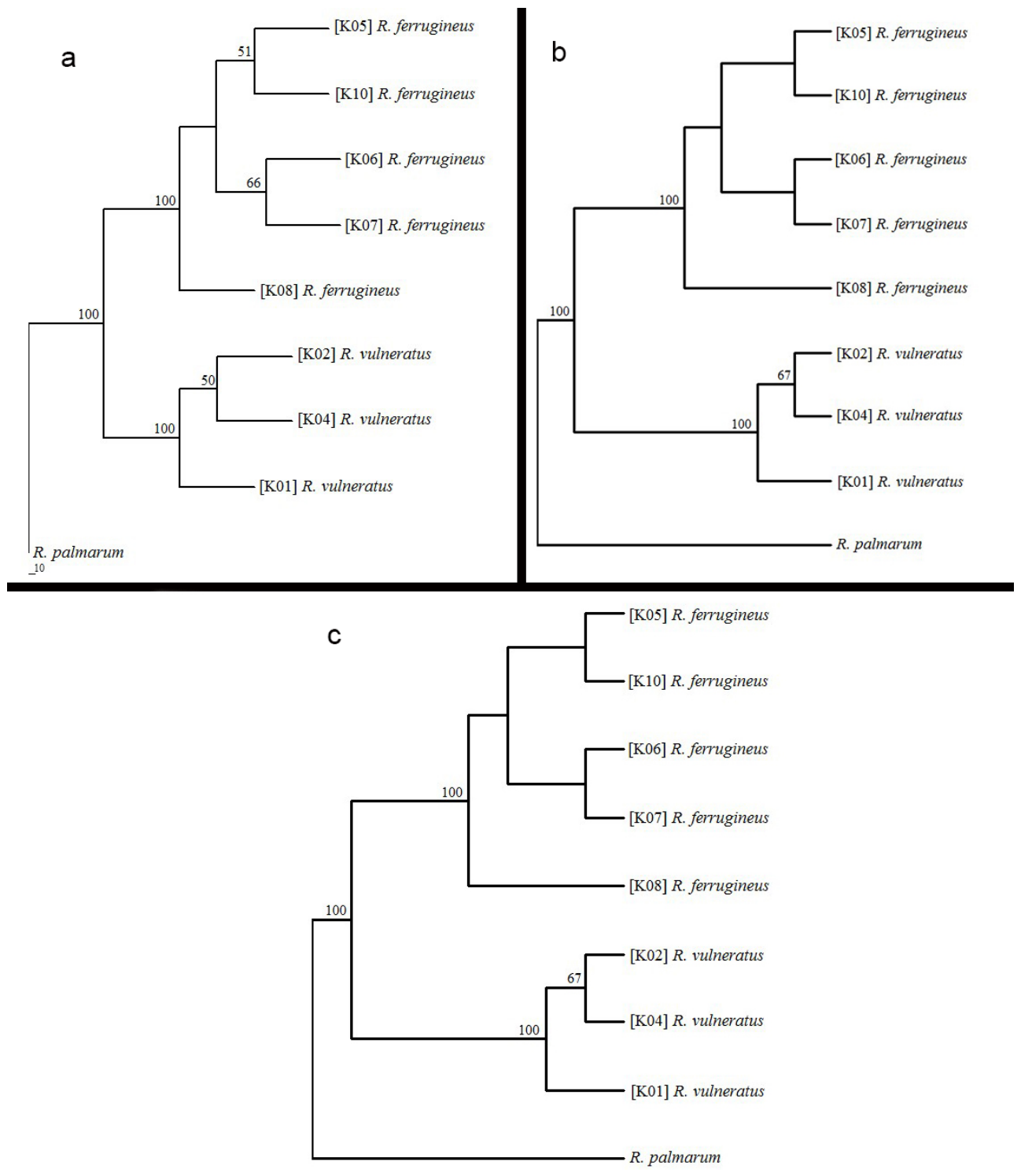

Figs. 2a-c. Phylogenetic tree of the Rhynchophorus ferrugineus and R. vulneratus based on NJ (a), MP (b) and $\mathrm{BI}(\mathrm{c})$ analyses using Cytb data sequences. 
AMAN-ZUKI, A., GHAZALI, S.Z., BADRULISHAM, A.S., et al.

\begin{tabular}{|c|c|c|c|c|c|c|c|c|c|c|c|c|c|c|c|}
\hline$\stackrel{\sqrt{n}}{=}$ & & & & & & & & & & & & & & & \\
\hline$\stackrel{\Im}{\Xi}$ & & & & & & & & & & & & & & & $\begin{array}{l}\infty \\
\stackrel{\infty}{\circ} \\
0 \\
\end{array}$ \\
\hline$\stackrel{\underline{m}}{=}$ & & & & & & & & & & & & & & 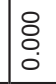 & $\begin{array}{l}\stackrel{\infty}{\circ} \\
\stackrel{\circ}{0} \\
\end{array}$ \\
\hline$\stackrel{\widehat{N}}{\Xi}$ & & & & & & & & & & & & & 웅 & 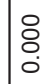 & $\frac{\infty}{\stackrel{\infty}{\circ}}$ \\
\hline E & & & & & & & & & & & & 웅 & ○. & 웅 & $\begin{array}{l}\infty \\
\stackrel{\infty}{\circ} \\
\end{array}$ \\
\hline$\stackrel{o}{\varrho}$ & & & & & & & & & & & 웅 & $\begin{array}{l}\text { ò } \\
\text {. }\end{array}$ & 웅 & 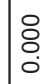 & $\frac{\infty}{\stackrel{\infty}{\circ}}$ \\
\hline$\widehat{\Phi}$ & & & & & & & & & & 离 & $\begin{array}{l}\circ \\
0 \\
0\end{array}$ & 웅 & $\begin{array}{l}8 \\
0 \\
0\end{array}$ & 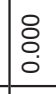 & 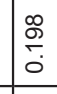 \\
\hline 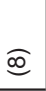 & & & & & & & & & $\begin{array}{l}\hat{y} \\
0 \\
0\end{array}$ & 妾 & 势 & $\begin{array}{l}\hat{y} \\
\text { Oे }\end{array}$ & $\begin{array}{l}\text { fo } \\
0 \\
0\end{array}$ & 它 & 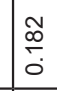 \\
\hline$E$ & & & & & & & & 웅 & 守 & 妾 & $\begin{array}{l}\text { fy } \\
\text { O }\end{array}$ & 告 & $\begin{array}{l}\text { fo } \\
\text { Oे }\end{array}$ & 势 & 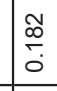 \\
\hline$\widehat{\theta}$ & & & & & & & 文 & p. & 守 & 告 & 势 & $\begin{array}{l}\text { fo } \\
\text { Oे. }\end{array}$ & $\begin{array}{l}\text { fo } \\
\text { Oे }\end{array}$ & 告 & 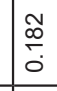 \\
\hline$\sqrt{6}$ & & & & & & o & 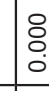 & p. & 守 & 妾 & $\begin{array}{l}\text { fo } \\
0\end{array}$ & 告 & $\begin{array}{l}\text { fo } \\
\text { Oे }\end{array}$ & 容 & 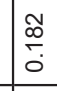 \\
\hline Ð & & & & & 오․ & $\begin{array}{l}\text { ¿े } \\
\text { ¿ }\end{array}$ & 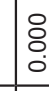 & p. & 守 & 守 & 守 & 告 & $\begin{array}{l}\text { yे } \\
\text { Oे }\end{array}$ & 柋 & 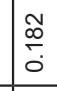 \\
\hline$\widehat{\text { ल }}$ & & & & $\begin{array}{l}\stackrel{0}{0} \\
\stackrel{m}{0}\end{array}$ & $\begin{array}{l}0 \\
\stackrel{0}{0} \\
0\end{array}$ & 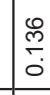 & $\mid \stackrel{\circ}{\check{c}}$ & 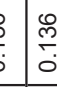 & : & $\frac{\circ}{\circ}$ & 号 & $\frac{0}{\circ}$ & $\frac{\circ}{\circ}$ & $\frac{0}{0}$ & $\begin{array}{l}0 \\
\\
0\end{array}$ \\
\hline$\widehat{\widehat{N}}$ & & & 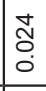 & 兽 & $\begin{array}{l}\stackrel{8}{m} \\
\text { c. }\end{array}$ & 兽 & 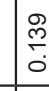 & 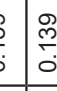 & : & 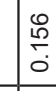 & $\begin{array}{l}\stackrel{\circ}{\circ} \\
\stackrel{\rho}{0} \\
\end{array}$ & $\begin{array}{l}\stackrel{\circ}{0} \\
\stackrel{\circ}{0} \\
\end{array}$ & $\begin{array}{l}\stackrel{0}{\circ} \\
\stackrel{2}{0} \\
\end{array}$ & 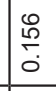 & 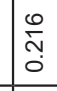 \\
\hline$\Xi$ & & $\begin{array}{l}\text { Õ } \\
\text { Oे } \\
0\end{array}$ & \begin{tabular}{|l} 
\\
o \\
0 \\
0
\end{tabular} & $\frac{\bar{\tau}}{\dot{\sigma}}$ & 文 & 亲 & $\frac{5}{5}$ & 5 & 通 & 点 & $\frac{\circ}{\circ}$ & $\frac{\circ}{\circ}$ & 总 & $\frac{0}{0}$ & ָ̃ \\
\hline & 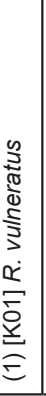 & 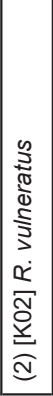 & 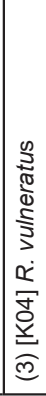 & 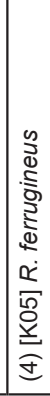 & 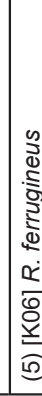 & 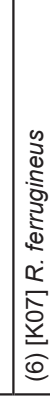 & 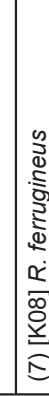 & 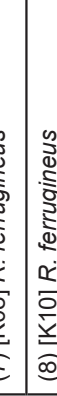 & 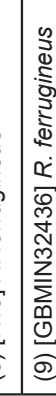 & 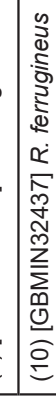 & 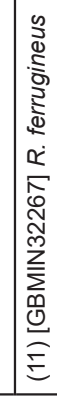 & 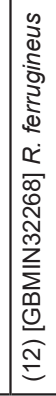 & 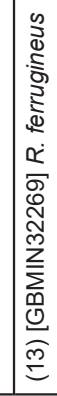 & 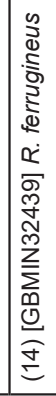 & 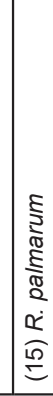 \\
\hline
\end{tabular}


Proof on the Divergence Times of $R$. ferrugineus and $R$. vulneratus

Table 3. Genetic distance of species, $R$. vulneratus, $R$. ferrugineus and $R$. palmarum using Cytb data.

\begin{tabular}{|l|l|l|l|l|l|l|l|l|l|}
\hline & $\mathrm{K} 01$ & $\mathrm{~K} 02$ & $\mathrm{~K} 04$ & $\mathrm{~K} 05$ & $\mathrm{~K} 06$ & $\mathrm{~K} 07$ & $\mathrm{~K} 08$ & $\mathrm{~K} 10$ & R. palmarum \\
\hline [K01] R. vulneratus & - & & & & & & & & \\
\hline$[\mathrm{K} 02]$ R. vulneratus & 0.019 & & & & & & & & \\
\hline$[$ K04] R. vulneratus & 0.019 & 0.016 & & & & & & & \\
\hline [K05] R. ferrugineus & 0.146 & 0.154 & 0.149 & & & & & & \\
\hline [K06] R. ferrugineus & 0.143 & 0.157 & 0.153 & 0.003 & & & & & \\
\hline [K07] R. ferrugineus & 0.143 & 0.157 & 0.153 & 0.003 & 0.000 & & & & \\
\hline [K08] R. ferrugineus & 0.150 & 0.157 & 0.153 & 0.003 & 0.005 & 0.005 & & & \\
\hline [K10] R. ferrugineus & 0.150 & 0.157 & 0.153 & 0.003 & 0.005 & 0.005 & 0.005 & & \\
\hline R. palmarum & 0.282 & 0.292 & 0.282 & 0.294 & 0.290 & 0.290 & 0.299 & 0.300 & \\
\hline
\end{tabular}
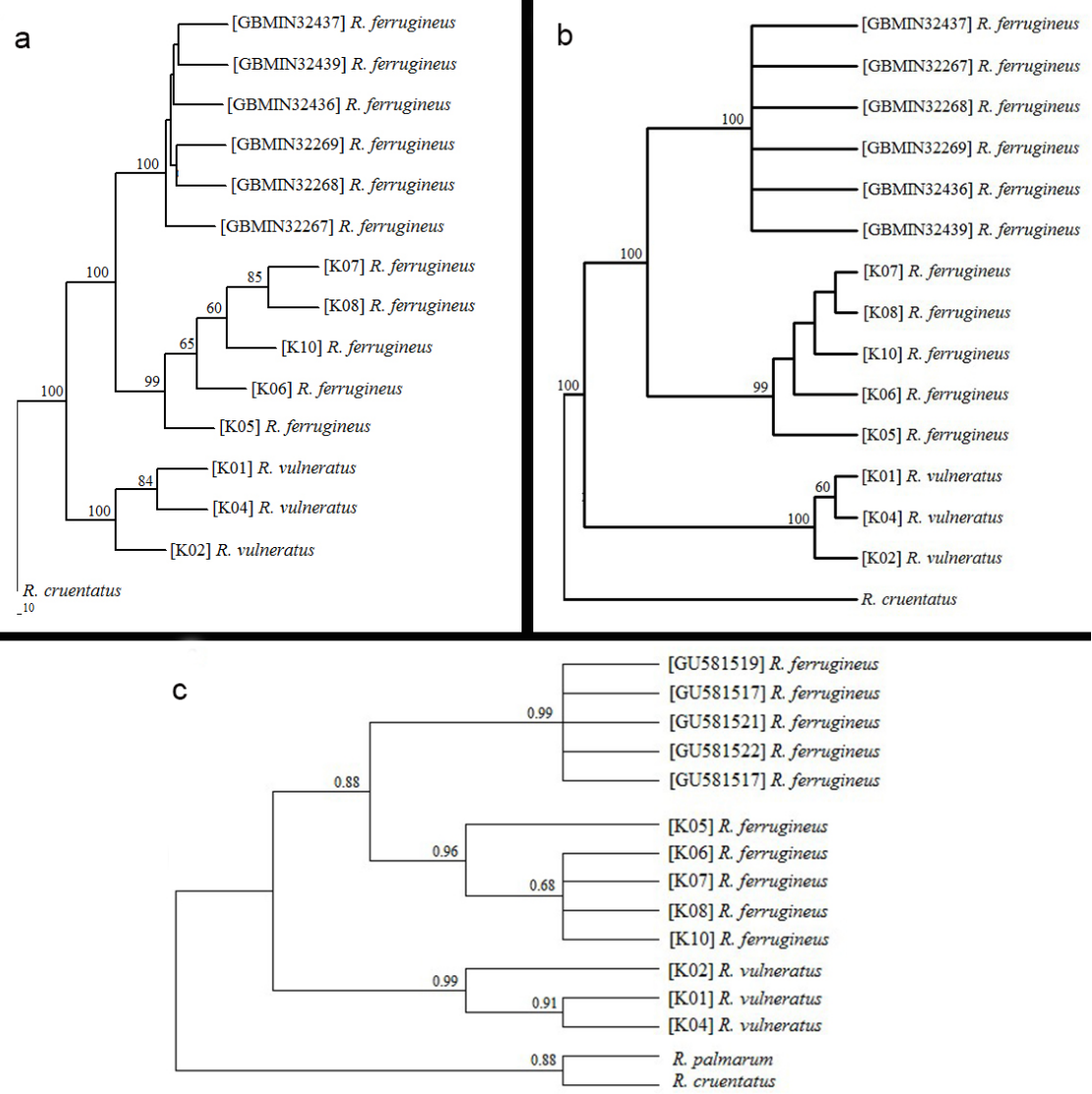

Figs. 3a-c. Phylogenetic tree of the Rhynchophorus ferrugineus and R. vulneratus based on NJ (a), MP (b) and $\mathrm{BI}(\mathrm{c})$ analyses using $\mathrm{CO}$ sequences data. 
AMAN-ZUKI, A., GHAZALI, S.Z., BADRULISHAM, A.S., et al.
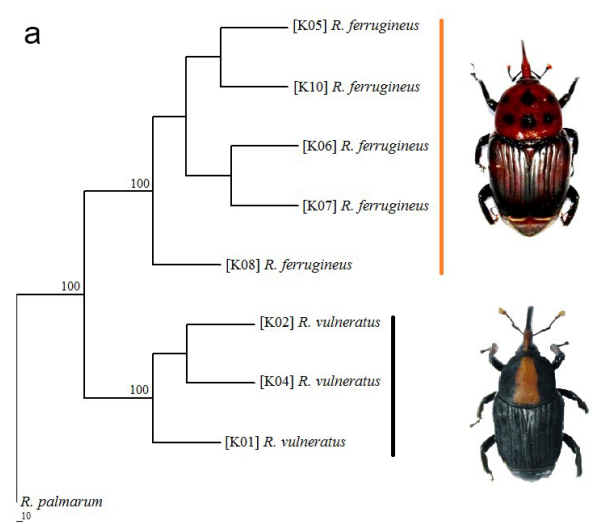

$\mathrm{b}$
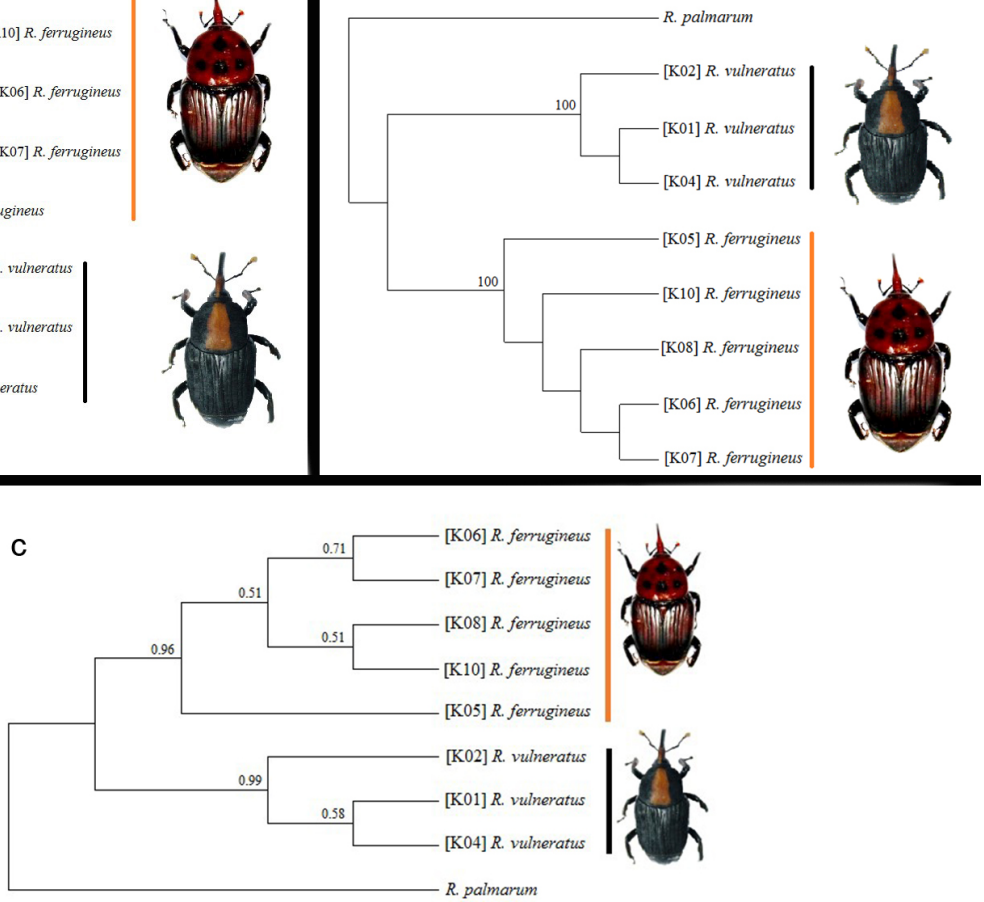

Figs. 4a-c. Phylogenetic tree of the Rhynchophorus ferrugineus and R. vulneratus based on NJ (a), MP (b) and $\mathrm{BI}(\mathrm{c})$ analyses using combination of $\mathrm{Cytb}+\mathrm{CO}$ sequences data.

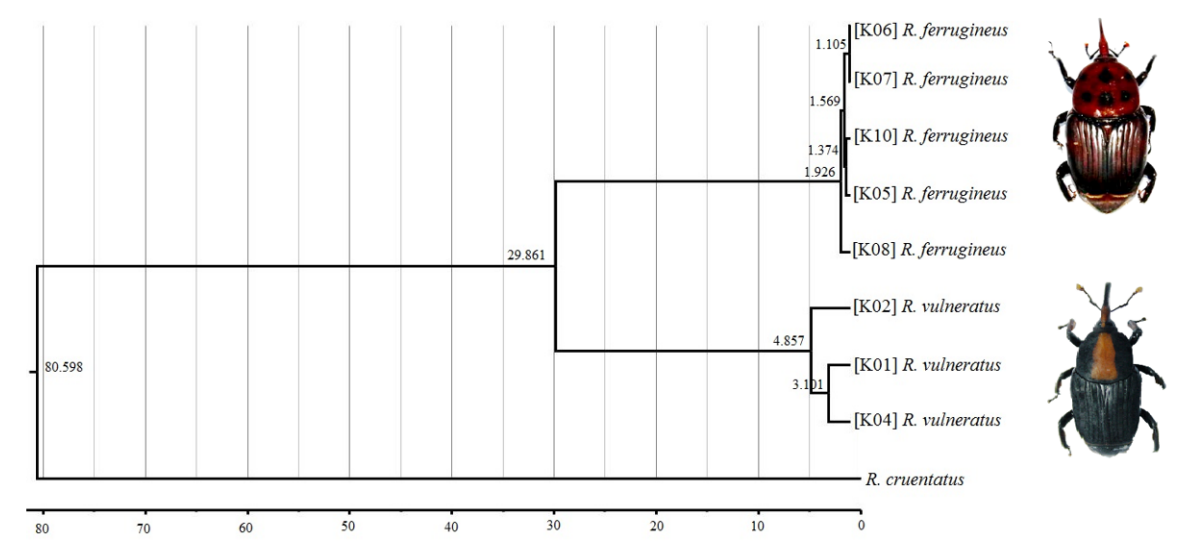

Figs. 5. Molecular clock tree of Rhynchophorus ferrugineus and R. vulneratus using combination of Cytb $+\mathrm{CO}$ sequences data.

Even though the body colour and spots could not clearly differentiate the two studied species, $R$. ferrugineus and $R$. vulneratus, the $\mathrm{CO} /$ marker on the other hand, 
Proof on the Divergence Times of $R$. ferrugineus and $R$. vulneratus

has shown a species separation. Although a small number of weevil specimens was examined in this study as compared to that of (Rugman-Jones et al 2013), a study of the species time divergence to clarifying the $R$. ferrugineus and $R$. vulneratus as a sympatric species would be the most effective method and a significant item to be measured and investigated, despite the fact the factors for the speciation of the species are still very much in doubt. In addition, only a small scale of samples need to be utilized to elucidate a complex morphology or cryptic species. Likewise, there had also been similar studies on the different genetic data among cryptic species of gecko (Oliver, Adams, \& Doughty, 2010), and we believed that this could reveal a similar pattern in insect species.

Previous studies on $R$. ferrugineus and $R$. vulneratus only focused on either morphological (Wattanapongsiri, 1966; Sazali, Hazmi, Abang, \& Jemain, 2018) or molecular (Rugman-Jones et al, 2013) aspects but none reported on the incorporation of both aspects and species, except by Hallet et al (2004). As a result, various conclusions regarding the species status of $R$. ferrugineus and $R$. vulneratus were presented. According to Wattanapongsiri (1966), the identification of $R$. ferrugineus and $R$. vulneratus was mainly based on the colour morph, the shape of the pronotum as the second morphological characters while Rugman-Jones et al (2013) debunked that the protonum shape was one of the distinguished characters in two species. A study by Sazali et al (2018) reported that the morphological differences between $R$. ferrugineus and $R$. vulneratus were significant in terms of the size of the species. Rhynchophorus vulneratus is slightly larger compared to $R$. ferrugineus with the length of pronotum for $R$. vulneratus is measuring $12.87 \mathrm{~mm}$, while for $R$. ferrugineus it is $11.51 \mathrm{~mm}$, and the mean width of elytra is $13.60 \mathrm{~mm}$, it is $11.44 \mathrm{~mm}$ for $R$. vulneratus and $R$. ferrugineus, respectively.

Results from the molecular studies indicated that $R$. ferrugineus and $R$. vulneratus differed from each other and this was supported by the morphological features depicted by Wattanapongsiri (1966). According to Hallett et al (2004), the crossbred of $R$. ferrugineus and $R$. vulneratus have successfully produced a fertile F1. However, the survival of the hybrid was not further discussed in the paper. Additionally, they provided a weak single proof of DNA similarity in which only $201 \mathrm{bp}$ of mitochondrial DNA sequence in the $\mathrm{CO}$ gene were identical between the two species. In addition, a study by Sukirno et al (2018) had confirmed that the undescribed color polymorphism existed in Indonesia $R$. vulneratus samples, in which rusty red polymorphisms had been wrongly identified as $R$. ferrugineus. The low interspecific variability was also detected in $\mathrm{CO}$ sequences in the Indonesia and Saudi Arabia samples, despite $\mathrm{COI}$ having proven to be a great marker for species separation. Sukirno, Tufail, Rasool, \& Aldawoo (2020) also had stated that pronotal markings and COI sequences were able to separate the $R$. ferrugineus under three haplotypes number. Moreover, in this study, the COI marker has proven effective in species separation, especially on the Malaysian samples, but using different primers that have not been used earlier by Sukirno et al (2018) and Sukirno, Tufail, Rasool, Husain, \& Aldawood (2020b). 
Referring to Filchak, Roethele, \& Feder (2000), speciation may occur due to changes in hosts and does not only depend upon geographical isolation integrating sterility and life development. We assumed that the changing of the pronotum coloration in both Rhynchophorus species from orange or black marking ( $R$. ferrugineus) to black or red stripe ( $R$. vulneratus) or vice versa indicated major changes in the evolution and speciation to finally become two distinct species. A study by Kelley, Fitzpatrick, \& Merilaita (2013) also reported that the coloration and spots of coral reef fishes were investigated, and they found that the presence of spots and stripes on the fish body were correlated with several parameters. Due to this, fish biology seems to be developing as a whole in parallel with the fish's evolution, for example in body length, feeding behavior and habitat preferences.

To date, no clear studies have been performed on biological and geographical factors that separate the weevil species from Malaysia and other areas in their native range. Furthermore, the divergence time for both species took place much earlier at $\approx 29.861 \pm 10$ mya. The molecular clock analysis also revealed that $R$. vulneratus formed as a new species earlier at $\approx 4.857 \pm 10$ mya as compared to $R$. ferrugineus at $\approx 1.926 \pm 10$ mya. These findings provide a baseline data of molecular clock study in Rhynchophorus spp. regardless of the sample size.

In terms of evolutionary processes, we hypothesize that the changes in coloration from a fully black weevil ( $R$. palmarum) to black or red stripe ( $R$. vulneratus) is a characteristic that commonly changes through evolution. For example, a similar change took place in the Timema species of walking sticks in their dorsal stripes through their interactions with the host plants (Sandoval \& Crespi, 2008; Farkas et al, 2013). However, this process required a very long time due to geographical isolation in parallel with a gradual process of speciation that led to reproductive isolation (Mayr, 1942 ). In this situation, we believed that $R$. palmarum, which is native to South America and countries nearby, took approximately 500,000 years to become $R$. vulneratus is native to Southeast Asia and Indo-Malaya.

Furthermore, both sympatric species started diverging into different subpopulations from 29.861 mya and started to speciate after a relatively short time, approximately 3 mya. This may have been influenced by changing the host plant from the coconut tree to the date tree. We believed that the process started in an area where both coconut and date trees grew together. For this reason, competition occurred that correlated with the availability of the plant host itself as a food source. A population of $R$. vulneratus changed its host plant from coconut to date trees and had speciated to form $R$. ferrugineus within a short time. Similar events have happened in species not limited to insects as seen in studies by Bush et al (1989), Bush \& Butlin, (2004), but also in other kinds of animal species, for example in the coral-dwelling fish genus Gobiodon (Munday, Van Herwerden, \& Dudgeon, 2004).

The results of the molecular clock analysis of this study supported that $R$. ferrugineus and $R$. vulneratus were two valid species with $R$. vulneratus being formed as a new species earlier than $R$. ferrugineus. The time of separation for $R$. ferrugineus and $R$. vulneratus is generally accepted as that for the separation of $R$. ferrugineus, 
Proof on the Divergence Times of $R$. ferrugineus and $R$. vulneratus

which for $R$. bilineatus, $R$. phoenicis, $R$. cruentatus and $R$. palmarum was from 2.3 to 3.7 million years ago. Furthermore, a study by Hallett et al (2004) stated that $R$. ferrugineus and $R$. vulneratus had separated from $R$. bilineatus about 5 million years ago.

In this study, the genetic distance among members of $R$. vulneratus was higher than that of $R$. ferrugineus for both markers, indicating a high divergence in $R$. vulneratus species (Figs. 2-4, Table 2-3). However, the value of the $\mathrm{CO}$ obtained from the genetic distance analysis was lower (0.000-0.047) compared to the values obtained by El-Mergawy et al (2011) in $R$. ferrugineus at a range of 0.058-0.095. Even though the results showed slight difference in the genetic distance value however, there are a few assumptions that can be made regarding this situation. Firstly, there may be cryptic species within $R$. vulneratus that have created a higher genetic distance value (Rugman-Jones et al, 2013). Secondly, the occurrence of sympatry within the $R$. vulneratus species may create higher values for genetic distance. Sympatry within species has been reported in Curculionidae, for example in the Laparocerus weevil (Faria et al, 2016) and Mecinus weevil (ToŠevski et al, 2011). Furthermore, high genetic diversity is a characteristic exhibited in the native range of the species. For example, the high genetic diversity in $R$. ferrugineus from Pakistan indicates that this species is native to Pakistan (Yasin, Rugman-Jones, Wakil, \& Stouthamer, 2016).Molecular clock studies provide important information regarding the species being studied. In our study, molecular clock analysis was able to prove the status of $R$. ferrugineus and $R$. vulneratus as two valid species. Likewise, a study by (Zhang et al, 2005) provided proof of the existence of a Coptalabrus species (Carabidae) using the divergence time derived from a phylogeographic study of this species in South Korea. This demonstrates that information regarding divergence time is important for phylogeographic study. This is because phylogeographic study involves the evolutionary history, population genetics, geography and divergence time of the species (Edwards \& Beerli, 2000).

\section{CONCLUSION}

Molecular clock analysis using the combined data of $\mathrm{COI}$ and Cytb has firmly separated the sympatric species, $R$. ferrugineus and $R$. vulneratus. Based on the divergence time, we have discovered that the species speciate to form $R$. ferrugineus from $\approx 1.926 \pm 10$ mya and $R$. vulneratus $\approx 4.857 \pm 10$ mya. The separation was also supported by phylogenetic analyses of NJ, MP and BI, as well as proven by the data of the distance analysis. The information gathered by this study will be able to provide information for future regional studies related to the RPW.

\section{ACKNOWLEDGEMENTS}

The authors would like to thank Mr. Mohamad Harris Nasir for the samples and Dr Johari Jalinas for the comments and suggestions. The authors would like to thank Prof. Dr. Maimon Abdullah for her kind editing and critical comments of the final draft copy of this publication. This research was funded by GUP-2018-037 research grant. 
AMAN-ZUKI, A., GHAZALI, S.Z., BADRULISHAM, A.S., et al.

\section{REFERENCES}

Aman-Zuki, A., Mohammed, M.A., Md Zain, B.M., \& Yaakop, S. (2019). Phylogenetic Relationships of five Oriental Apanteles species-groups (Hymenoptera: Braconidae: Microgastrinae) by concatenating four molecular markers. Journal of Asia-Pacific Entomology, 22(1), 341-352.

Bush, G.L. \& Butlin, R.K. (2004). Sympatric speciation in insects. Adaptive Speciation, 229-248.

Bush, G., Feder, J., Berlocher, S., McPheron, B., Smith, D.C., \& Chilcote, C. (1989). Sympatric origins of $R$. pomonella. Nature, 339(6223), 346.

Drummond, A.J., Ho, S.Y., Phillips, M.J., \& Rambaut, A. (2006). Relaxed phylogenetics and dating with confidence. Plos Biology,4(5), e88.

Drummond, A.J. \& Rambaut, A. (2007). Beast bayesian evolutionary analysis by sampling trees. BMC Evolutionary Biology, 7(1), 214.

Edwards, S.V. \& Beerli, P. (2000). Perspective: gene divergence, population divergence, and the variance incoalescence time in phylogeographic studies. Evolution, 54(6), 1839-1854.

El-Mergawy, R.A.A., Faure, N., Nasr, M.I., Avand-Faghih, A., Rochat, D., \& Silvain, J.F. (2011). Mitochondrial genetic variation and invasion history of red palm weevil, Rhynchophorus ferrugineus (Coleoptera: Curculionidae). International Journal of Agriculture and Biology,13, 631-637.

Faria, C.M., Machado, A., Amorim, I.R., Gage, M.J., Borges, P.A., \& Emerson, B.C. (2016). Evidence for multiple founding lineages and genetic admixture in the evolution of species within an oceanic island weevil (Coleoptera, Curculionidae) super radiation. Journal of Biogeography, 43(1), 178-191.

Farkas, T.E., Mononen, T., Comeault, A.A., Hanski, I., \& Nosil, P. (2013). Evolution of camouflage drives rapid ecological change in an insect community. Current Biology, 23(19), 1835-1843.

Felsenstein, J. (1985). Confidence limits on phylogenies: an approach using the bootstrap. Evolution, 39(4), 783-791.

Filchak, K.E., Roethele, J.B., \& Feder, J.L. (2000). Natural selection and sympatric divergence in the apple maggot Rhagoletis pomonella. Nature, 407(6805), 739-742.

Giblin-Davis, R.M., Faleiro, J.R., Jacas, J.A., Peña, J.E., \& Vidyasagar, P.S.P.V. (2013). Biology and management of the red palm weevil, Rhynchophorus ferrugineus. Potential Invasive Pests of Agricultural Crops (Eds Peña JE), 1-34.

Halim, M., Aman-Zuki, A., Syed Ahmad, S.Z., Mohammad Din, A.M.M., Abdul Rahim, A., Mohd Masri, M.M., Md Zain, B.M., \& Yaakop, S. (2018). Exploring the abundance and DNA barcode information of eight parasitoid wasps species (Hymenoptera), the natural enemies of the important pest of oil palm, bagworm, Metisa plana (Lepidoptera: Psychidae) toward the biocontrol approach and it's application in Malaysia. Journal of Asia-Pacific Entomology, 21(4), 1359-1365.

Hallett, R.H., Crespi, B.J., \& Borden, J.H. (2004). Synonymy of Rhynchophorus ferrugineus (Olivier), 1790 and R. vulneratus (Panzer), 1798 (Coleoptera, Curculionidae, Rhynchophorinae). Journal of Natural History, 38(22), 2863-2882.

Hallett, R.H., Gries, G., Gries, R., Borden, J.H., Czyzewska, E., Oehlschlager, A.C., Pierce, H.D., Angerilli, N.P.D., \& Rauf, A. (1993). Aggregation Pheromones of Two Asian Palm Weevils, Rhynchophorus ferrugineus and R. vulneratus. Naturwissenschaften, 80(7), 328-331.

Heath, T.A., Huelsenbeck, J.P., \& Stadler, T. (2014). The fossilized birth-death process for coherent calibration of divergence-time estimates. Proceedings of the National Academy of Sciences, 111(29), e2957-e2966.

Herbst, J.F.W. (1795). Natursystem aller bekannten in- und ausländischenInsektenals eine fortsezzung der von büffonschen naturgeschichte. Der KäferSechster Theil,1-520.

Hillis, D.M., Moritz, C., \& Mable, B.K. (1996). Molecular systematics. (2nd ed.) Sinauer Associates, Sunderland, MA. 
Proof on the Divergence Times of $R$. ferrugineus and R. vulneratus

Huelsenbeck, J.P., Larget, B., \& Alfaro, M.E. (2004). Bayesian Phylogenetic Model Selection Using Reversible Jump Markov chain Monte Carlo. Molecular biology and. evolution, 21(6), 1123-1133.

Idris, A.B., Mokhtaruddin, H., Zazali, C., Nurul Wahida, O., Yaakop, S., \& Hazmi, I.R. (2014). The Potential of Red Palm Weevil Infesting and Destroying Oil Palm Industry in Malaysia. The Planter, Kuala Lumpur, 90(1058), 329-335.

Kelley, J.L., Fitzpatrick, J.L., \& Merilaita, S. (2013). Spots and stripes: ecology and colour pattern evolution in Butterflyfishes. In Proceeding Biological Science Royal Society B: Biological Sciences, 280(175), 2012-2730.

Kimura, M. \& Ohta, T. (1972). On the stochastic model for estimation of mutational distance between homologous proteins. Journal of Molecular Evolution, 2(1), 87-90.

Löhr, B., Vásquez-Ordóñez, A.A., \& Lopez-Lavalle, L.A.B. (2015). Rhynchophorus palmarum In Disguise: Undescribed Polymorphism In the "Black" Palm Weevil. Plos One, 10(12), e0143210.

Mayr, E. (1942). Systematics and the origin of species. Columbia University Press, New York.

Mazza, G., Francardi, V., Simoni, S., Benvenuti, C., Cervo, R., Faleiro, J.R., Llácer, E., Longo, S., Nannelli, R., Tarasco, E., \& Roversi, P.F. (2014). An overview on the natural enemies of Rhynchophorus Palm weevils, with focus on R. ferrugineus. Biological Control, 77, 83-92.

Mohammed, M.A., Aman-Zuki, A., Yusof, S., Md-Zain, B.M., \& Yaakop, S. (2017). Prevalence and evolutionary history of endosymbiont Wolbachia (Rickettsiales: Anaplasmataceae) in parasitoids (Hymenoptera: Braconidae) associated with Bactrocera fruit flies (Diptera: Tephritidae) infesting carambola. Entomological science, 20(1), 382-395.

Monteiro, A. \& Pierce, N.E. (2001). Phylogeny of Bicyclus (Lepidoptera: Nymphalidae) Inferred from COI, COII, and EF-1a Gene Sequences. Molecular Phylogenetics and Evolution, 18(2), 264-281.

Molet, T., Roda, A.L., \& Jackson, L.D. (2011). CPHST Pest Datasheet for Rhynchophorus ferrugineus. USDA-APHIS-PPQ-CPHST.

Munday, P.L., Van Herwerden, L., \& Dudgeon, C.L. (2004). Evidence for sympatric speciation by host shift in the sea. Current Biology, 14, 1498-1504.

Oliver, P.M., Adams, M., \& Doughty, P. (2010). Molecular evidence for ten species and oligo-miocene vicariance within a nominal Australian gecko species (Crenadactylus ocellatus, Diplodactylidae). BMC Evolutionary Biology, 10(1), 386.

Posada, D. (2008). Model test: phylogenetic model averaging. Molecular Biology and Evolution, 25(7), $1253-1256$.

Rambaut, A. \& Drummond, A.J. (2015, November, 13). FigTree, ver. 1.4 2. Retrieved from http:/tree. bio. ed. ac. uk/software/figtree/.

Ronquist, F., Teslenko, M., van der Mark, P., Ayres, D.L., Darling, A., Höhna, S., Larget, B., Liu, L., \& Suchard, M.A., Huelsenbeck, J.P. (2012). MrBayes 3.2: Efficient bayesian phylogenetic inference and model choice across a large model space. Systematic Biology, 61(3), 539-542.

Rugman-Jones, P.F., Hoddle, C.D., Hoddle, M.S., \& Stouthamer, R. (2013). The lesser of two weevils: molecular-genetics of pest palm weevil populations confirm Rhynchophorus vulneratus (Panzer 1798) As a valid species distinct from $R$. ferrugineus (Olivier 1790) and reveal the global extent of both. Plos One, 8(10), e78379.

Sandoval, C.P. \& Crespi, B.J. (2008). Adaptive evolution of cryptic coloration: the shape of host plants and dorsal stripes in Timema Walking-sticks. Biological Journal of the Linnean Society, 94: 1-5.

Sazali, S.N., Hazmi, I.R., Abang, F., \& Jemain, A.A. (2018). Morphometric study of the palm weevils, Rhynchophorus vulneratus and $R$. ferrugineus (Coleoptera: Curculionidae) in view of insular and mainland populations of Malaysia. Pertanika Journal of Tropical Agricultural Science, 41(3), $1329-1340$.

Simon, C., Frati, F., Beckenbach, A., Crespi, B., Liu, H., Flook, P., 1994, Evolution, weighting, and phylogenetic utility of mitochondrial gene sequences and a compilation of conserved polymerase chain reaction primers. Annals of the Entomological Society of America, 87(6), 651-701. 
Smith, P.T. \& Kambhampati, S. (1999). Status of the Cotesia flavipes species complex (Braconidae: Microgastrinae) based on mitochondrial 16S rRNA and NADH 1 dehydrogenase gene sequence. Journal of the Kansas Entomological Society, 306-314.

Smith, P.T., Kambhampati, S., Völkl, W., \& Mackauer, M. (1999). A phylogeny of aphid parasitoids (Hymenoptera: Braconidae: Aphidiinae) inferred from Mitochondrial NADH 1 dehydrogenase gene sequence. Molecular Phylogenetics and Evolution, 11(2), 236-245.

Stadler, T., Gavryushkina, A., Warnock, R.C., Drummond, A.J., \& Heath, T.A. (2018). The fossilized birth-death model for the analysis of stratigraphic range data under different speciation modes. Journal of Theoretical Biology, 447, 41-55.

Suchard, M.A., Lemey, P., Baele, G., Ayres, D.L., Drummond, A.J., \& Rambaut, A. (2018). Bayesian phylogenetic and phylodynamic data Integration using BEAST 1.10 Virus Evoution,4 (1), vey016.

Sukirno, S., Tufail, M., Rasool, K.G, \& Aldawoo, A.S. (2018). Undescribed color polymorphism of the asiatic palm weevil, Rhynchophorus vulneratus Panzer (Coleoptera: Curculionidae) in Indonesia: biodiversity study based on COI gene. Florida Entomologist, 101(4), 642-648.

Sukirno, S., Tufail, M., Rasool, K.G., Husain, M., \& Aldawood, A.S. (2020). Diversity of red palm weevil, Rhynchophorus ferrugineus Oliv. (Coleoptera: Curculionidae) in the Kingdom of Saudi Arabia: studies on the phenotypic and DNA barcodes. International Journal of Tropical Insect Science 40(4), 899.

Swofford, D.L. (1998). PAUP*: Phylogenetic analysis using parsimony (and other methods). Sunderland, MA: Sinauer Associates.

ToŠevski, I., Caldara, R., Joviĉ, J., Hernăndez-Vera, G., Baviera, C., Gassmann, A., \& Emerson, B.C., (2011). Morphological, molecular and biological evidence reveal two cryptic species in Mecinusjanthinus Germar (Coleoptera, Curculionidae), a successful biological control agent of dalmatian toadflax, Linaria dalmatica (Lamiales, Plantaginaceae). Systematic Entomology, 36(4), 741-753.

Wattanapongsiri, A.A. (1966). Revision of the genera Rhynchophorus and Dynamis (Coleoptera: Curculionidae). Department of Agriculture Science, Bangkok, Thailand Bulletin, 1, 1-328.

Weissling, T.J. \& Giblin-Davis, R.M. (1997). Palmetto weevil, Rhynchophorus cruentatus Fabricius (Insecta: Coleoptera: Curculionidae), Division of Plant Industry, University of Florida, Publication Number: EENY-13.

Yasin, M., Rugman-Jones, P.F., Wakil, W., \& Stouthamer, R. (2016). Mitochondrial DNA variation among populations of Rhynchophorus ferrugineus (Coleoptera: Curculionidae) from Pakistan. Journal of Insect Science, 16(1), 100.

Zhang, A.B., Kubota, K., Takami, Y., Kim, J.L., Kim, J.K., \& Sota, T. (2005). Species status and phylogeography of two closely related Coptolabrus species (Coleoptera: Carabidae) in South Korea inferred from mitochondrial and nuclear gene sequences. Molecular Ecology, 14(12), 3823-3841. 